Meta

Journal des traducteurs

Translators' Journal

\title{
Translation, Postcolonialism and Cultural Studies
}

\section{Sherry Simon}

Volume 42, numéro 2, juin 1997

Lexicologie et terminologie II (1) et Traduction et post-colonialisme en Inde

Translation and Postcolonialism: India (2)

URI : https://id.erudit.org/iderudit/004153ar

DOI : https://doi.org/10.7202/004153ar

Aller au sommaire du numéro

Éditeur(s)

Les Presses de l'Université de Montréal

ISSN

0026-0452 (imprimé)

1492-1421 (numérique)

Découvrir la revue

Citer cet article

Simon, S. (1997). Translation, Postcolonialism and Cultural Studies. Meta, 42(2), 462-477. https://doi.org/10.7202/004153ar

\section{Résumé de l'article}

Cet article s'inscrit dans la continuité des travaux de Gayatri Spivak et vise à prolonger la critique de cet auteur à l'encontre de l'insensibilité linguistique des cultural studies anglo-américaines. 


\title{
TRANSLATION, POSTCOLONIALISM AND CULTURAL STUDIES
}

\author{
SHERRY SIMON \\ Concordia University, Montréal, Canada
}

\begin{abstract}
Résumé
Cet article s'inscrit dans la continuité des travaux de Gayatri Spivak et vise à prolonger la critique de cet auteur à l'encontre de l'insensibilité linguistique des cultural studies angloaméricaines.
\end{abstract}

\begin{abstract}
Despite the intensity of its current interest in postcoloniality, Anglo-American culture studies remains impenitently monolingual. Few cultural-studies theorists investigate the specifically linguistic question of postcolonial cultural transactions, preferring to treat 'translation' as a metaphor. At the same time, translation studies has been slow to assimilate the complexities of culture in the postcolonial world. This article tries to show how the linguistic sensitivities of translation studies are essential to cultural studies, while, inversely, sensitivity to questions of power in cultural translation is needed in translation studies. The work of Gayatri Spivak is mobilized to this end.
\end{abstract}

It was only a question of time until cultural studies "discovered" translation. ${ }^{1}$ After all, the globalization of culture means that we all live in "translated" worlds, that the spaces of knowledge we inhabit assemble ideas and styles of multiple origins, that transnational communications and frequent migrations make every cultural site a crossroads and a meeting place. These ideas have become the accepted truths of our contemporaneity. The hybridization of diasporic culture and the mobility of all identities - including gender - are central to the concerns of cultural studies. These contestatory sites of identity have sharpened awareness of the cultural authority of language, and of the position of the speakers within dominant codes. Languages are understood to participate in the processes by which individual and collective selves are fashioned; the "weight of linguistic and cultural histories," "old tales and new tongues" are brought to bear on the relations between self and other (Arteaga 1994:2).

At present, however, translation is most often used by cultural studies theorists as a metaphor, a rhetorical figure describing on the one hand the increasing internationalization of cultural production and on the other the fate of those who struggle between two worlds and two languages. Women "translate themselves" into the language of patriarchy, migrants strive to "translate" their past into the present. Translation, as a tangible representation of a secondary or mediated relationship to reality, has come to stand for the difficulty of access to language, for a sense of exclusion from the codes of the powerful. For those who feel they are marginal to the authoritative codes of Western culture, translation stands as "a metaphor for their ambiguous experience in the dominant culture" (Castelli $1990: 25$ ). It is this ambiguity, the sense of not being at home within the idioms of power, that has led many women, as well as migrants like Salman Rushdie, to call themselves "translated beings" (Rushdie 1991: 13).

Homi Bhabha takes this metaphorization one step further, proposing "translational culture" as a new site of cultural production and as a new speaking position - as part of the processes by which "newness enters the world" (Bhabha 1994: 212). "There is 
overwhelming evidence of a more transnational and translational sense of the hybridity of imagined communities" (Bhabha: 5). This in-between space of negotiation no longer belongs only to exceptional beings (the great modernist writers, translators, privileged migrants) but more and more comes to represent the tensions of hybridity related to the postcolonial subject and even of the national citizen. This altered understanding of translation as an activity which destabilizes culture, which enacts cultural identity, is a vital contribution to understanding new modes of cultural exchange.

But what of the material realities of translation? The highly metaphorical language used to describe translation hides an insensitivity to the realities of languages in today's world. Anglo-American gender and cultural studies have been abundantly nourished through translations, and yet they rarely look critically at the translation practices through which they have come into being. Confidently conducted mainly in English, these studies give little attention to the specific languages of intellectual and cultural commerce in the world today. It is time then that attention turn to translation as a pivotal mechanism in creating and transmitting cultural values.

What I wish to suggest, in this article, are some of the ways the moving boundaries of culture and cultural identity affect the way translation is practiced and conceptualized. This revision of the boundaries of translation is enacted in literature and performance, as it is reframed in theoretical writings. Some of the most interesting challenges to the boundaries between literary genres and among national/cultural identities have been provided by women writers like Eva Hoffman, Christine Brooke-Rose, Nicole Brossard, Noëlle Janaczewska, and performance artist and theoretician Coco Fusco. But my invocation of these moving borders also includes a pedagogical agenda: I wish to propose ways in which translation and cultural studies can be more closely integrated, so that each can palliate the weaknesses and blind spots of the other. One of the most pertinent examples of such a project is provided by the "Politics of translation" by G. Spivak, which I will consider in detail in the second part of this article.

Cultural studies brings to translation an understanding of the complexities of gender and culture. It allows us to situate linguistic transfer within the multiple "post" realities of today: poststructuralism, postcolonialism and postmodernism. To present these influences very schematically, it could be said that the first emphasizes the power of language to construct rather than simply reflect reality; the second highlights the power relations which inform contemporary cultural exchanges; and the third emphasizes that, in a universe where total novelty is a rare phenomenon, a great deal of cultural activity involves the recycling of already existing material. All three of these perspectives gives heightened prominence to translation as an activity of cultural creation and exchange. All three "post" terms have shifted and refocused the boundaries of difference in language. They emphasize the multiplicity of languages circulating in the world today, the competition between local and global forms of expression, the reactualizations of cultural forms. Most crucially, they have irrevocably put to rest the myth of pure difference, showing that the passage from one location to another always involves displacements and changes in the relationship between both terms.

Translation studies, on the other hand, investigates the linguistic and textual realizations through which cultural exchange takes place. The potential of translation studies lies in its project to expose the pathways that create the movement of ideas and esthetic forms. These lines of transmission, opened up by the violence of colonialism, now crisscross the globe as a permanent feature of internationalized culture. Translation research maps out the intellectual and linguistic points of contact between cultures and makes visible the political pressures that activate them. It shows that, because there is no total equivalence between cultural systems, the alignment between source and target text is necessarily 
skewed. And it draws attention to language as a force through which experience is shaped.

Because contemporary national cultures are increasingly plural, and inhabited by diverse languages, it is not surprising that mixed codes - and other forms of incomplete translation - have come to figure prominently in contemporary literature. Translation and writing meet as practices of creation in texts which define themselves as forms of "border writing", in those areas Mary Louise Pratt (1992:6) has so aptly called the "contact zone." This is the place where cultures, previously separated, come together and establish ongoing relations. Historically, these zones have grown out of colonial domination and been characterized by "conditions of coercion, radical inequality and intractable conflict" (Pratt 1992: 6). Increasingly, however, we find that Western society as a whole has turned into an immense contact zone, where inter-cultural relations contribute to the internal life of all national cultures.

\section{THE "CULTURE" IN THE CULTURAL TURN}

The "cultural turn" in translation studies has begun the process of examining the ways in which translation is nourished by - and contributes to - the dynamics of cultural representation. The descriptive methods favoured by the polysystem theory have encouraged the study of large corpuses of specific translation genres: theatre (Brisset 1990), science fiction (Gouanvic 1994) or novels (Toury 1995). Examination of translation trends that prevail during specific periods brings an understanding of the larger cultural forces at work in translation. In addition, emphasis is placed on the material reality of translated texts, as separate from the originals. Numerous case studies show how translators actualize prevailing attitudes towards Otherness (Lefevere 1992a). The centrality of translation to the imposition and maintenance of colonialism, for instance, is a powerful case in point (Niranjana 1992; Rafael 1988). There is a recognition of the translator as fully engaged in the literary, social and ideological realities of his or her time.

But what is often missing from translation studies accounts is a clear definition of what "culture" means. While "culture" is recognized as one of the most difficult and overdetermined concepts in the contemporary human and social sciences, it often appears in translation studies as if it had an obvious and unproblematic meaning. Translators are told that in order to do their work correctly they must understand the culture of the original text, that texts are "embedded" in a culture. The more extensive is this "embedding," the more difficult it will be to find equivalents for terms and ideas (for instance, Snell-Hornby 1988: 41). The difficulty with such statements is that they seem to presume a unified cultural field which the term inhabits; the translator must simply track down the precise location of the term within it and then investigate the corresponding cultural field for corresponding realities. What this image does not convey is the very difficulty of determining "cultural meaning." This meaning is not located within the culture itself but in the process of negotiation which is part of its continual re-activation. The solutions to many of the translator's dilemmas are not to be found in dictionaries, but rather in an understanding of the way language is tied to local realities, to literary forms, and to changing identities. Translators must constantly make decisions about the cultural meanings which language carries, and evaluate the degree to which the two different worlds they inhabit are "the same." These are not technical difficulties; they are not the domain of specialists in obscure or quaint vocabularies. They demand the exercise of a wide range of intelligences. In fact the process of meaning transfer often has less to do with finding the cultural inscription of a term than in reconstructing its value.

Consider the following example from British cultural anthropology concerning the discussion by Rodney Needham of the possibility of translating the Nuer concept of 
"belief." The Nuer are the African group to which the British social anthropologist Evans-Pritchard devoted a major study (Needham 1972). Needham begins his discussion by underlining the very obvious difficulty of translating religious concepts. In his study, Evans-Pritchard had concluded that the Nuer have no verbal concept that can convey exactly what is understood by the English word believe. Needham observed that this conclusion contrasts strongly with other ethnographical accounts according to which certain peoples "believe" this or that. It also contrasts with the findings of missionaries who do, by contrast, find equivalence between Nuer terms and the notion of belief. The missionary translators, although careful and conscientious in their linguistic research, seem to rely on their own "dogmatic conceptions of their faith" and on "personal conviction" to determine translatability. While the anthropologist is hesitant to ascribe total transferability between the Nuer and the English languages, the missionaries take a confidently optimistic view of equivalence (Needham 1972:37-38).

Is the category of 'belief' and especially religious belief transferable from the Nuer language to European languages? Needham's subtle and exhaustive investigation into the question, heavily influenced by Wittgenstein, leads to an ambiguous answer. The question of equivalence cannot be decided once and for all. The adequacy of the translation can only be measured against the objectives of the translator (Needham 1972: 205). It is not entirely surprising that the Protestant missionaries conclude definitively that the Nuer do possess a category of religious belief, analogous to the Christian conception. A contrary conclusion would have made their task of Bible translation into Nuer extremely difficult. The anthropologist Evans-Pritchard believes, rather, that the interior categories of the Nuer religion remain inaccessible to the outside observer and therefore recalcitrant to translation. The apparently conflicting reports of the missionary and the ethnographer make clear that the meaning of "belief" says more about the ideological project of the translator than about the reality of the Nuer.

From this example, it is clear that "cultural meaning" is not to be discovered simply by tacking the linguistic statement against its ecological and conceptual backdrop. The question is not simply "what does the concept mean within a culture alien to us?" but "to what extent can we consider this concept equivalent or analogous to one which we can frame in our own terms?" The answer is to be found only in a value judgement decreeing the degree of possible equivalence between cosmogonies.

The history of religion is rife with such examples. We know that the Catholic church was forced to issue a decree against religious syncretism in the New World (The Council of Trent, 1545-1563) specifically forbidding certain kinds of "native" pictorial representations of the Deity as well as native terms for naming divine realities. Not all conceptions of divinity were considered equally appropriate; not all cultural expressions acceptable. While some early missionaries both in Mexico and Peru had thought that conversion could take place peacefully within the framework of indigenous languages and symbols, they were quickly prevented from pursuing this path. The ecclesiastical authorities considered that conversion could not be achieved without force. This violence included an attack on language and symbolism. Quechua terminology used to describe Christian concepts was carefully eliminated from dictionaries, catechisms, and manuals used to preach to Indians, and the same purist attitude defined all other aspects of Christian life in the Andes (MacCormack 1985: 456).

In other words, missionaries, who were widely regarded as experts on matters Indian, were never able to translate Christianity into Andean terms, "that is, to separate Christianity from its European cultural, sociological, and even political framework" (MacCormack 1985: 458). In imposing a translation strategy based on the nonequivalence between native and European concepts of the Divinity, the Catholic 
church made language an instrument in a practice of conversion based on coercion and violence.

Again, "cultural meaning" is hardly a given here. The names and meaning of Andean deities are relegated to the parochialism of the local and the limited; the name of the European god is given the epistemological privilege of universality.

Entering another area of cultural contention, consider the "meaning" of the ecclesiastical swear-words common in Quebec French. What do words like câlice, baptême or tabernacle mean? On one level they refer to the vessels and the sacraments of the Church: the chalice, baptism, the tabernacle. Used commonly as swear-words (often "softened" into a deformed version of the word in order to limit offense, like tabernouche), they have obviously lost their referential meaning to become pure expletives. All the same, a translator may indeed wish to insist on the particular cultural history which has given rise to the prevalence of this ecclesiastical language, whose perversion yet attests to the imprint left by the Church. Do these words convey some essential information about living in Quebec? Would "damn" or "gosh" carry the same cultural weight?

In fact translators of Quebec literature into English have quite often left the expletives untranslated. They convey through this gesture an ethical posture: their conviction that an essential part of the meaning of this literature is its anchoring in a specific sociohistorical context (Simon 1992, 1995). This does not mean, however, that the relationship between language and cultural identity remains static. At the beginning of the century certain literary uses of vernacular French in Quebec literature pointed to a conservative and even archaic vision of that culture (in the novel Maria Chapdelaine and in its translation by W.H. Blake); the later integration of an anglicized, urban slang (joual) into literature pointed to the aggressive, self-conscious creation of an emergent culture. When seeking out or refusing English equivalents for this language, translators activate their readings of the way cultural meaning changes.

In order to determine meaning, therefore, and ensure its transfer adequately, the translator must engage with the values of the text. The translating project is essential to this transaction; it activates the implicit cultural meanings which are brought to bear.

\section{GAYATRI SPIVAK AND THE EROTICS OF TRANSLATION}

One theorist who has paid attention to the project of translation in the context of post-colonialism is Gayatri Spivak. With experience in the translation of Derrida, as well as texts by Mahasweta Devi and other Bengali writers, Spivak is one of the few cultural studies theorists to speak of translation from a practical as well as a theoretical point of view. She presents these ideas principally in "The Politics of Translation" (Spivak 1993), an article whose articulation of gender, culture and translation merits examination in some detail. As is always the case with Spivak's texts, no adequate summary can account for arguments which swirl and spiral, rather than unfold according to conventional rules of composition.

Spivak begins by emphasizing that the "task of the feminist translator is to consider language as a clue to the workings of gendered agency" (Spivak 1993:179). This agency is only partial, however, since the writer is always "written by her language," because even in acting intention "is not fully present to itself." But the writer also "writes agency" in accordance with her ideological position. Spivak provides a number of images of the translator's work which account for the complexity of agency. On the one hand she emphasizes the need for the translator to "surrender" to the text; on the other she speaks of the "staging" of language through translation. These illustrations of the subjective posture of the translator point to the first imperative of translation: the need to attend to the "rhetorical nature" of every language over its logical systematicity. 
This required attention to the rhetoricity of language, within a poststructuralist understanding of the text, is Spivak's main message to the translator. While this idea might not seem particularly new to literary translators of Western works (familiar with such theoreticians as Henri Meschonnic, Antoine Berman, Walter Benjamin or Paul de Man), Spivak insists on its dramatic pertinence as far as non-European works are concerned. The works of non-Western women are too often reduced to their social message, according to Spivak, or rendered in a flat international translatese which could have come from any far-away country. How can such texts compete for students' attention, when placed beside an Alice Walker or a Monique Wittig?

Spivak goes on to transform this message, this declaration of principle, into a method of translation. First, she explains how she had to undo previously taught habits of translation in order to learn how to engage fully with the text. Her school training had taught her only to produce an "accurate collection of synonyms." In her preface to a recently published translation of eighteenth century Bengali poetry, she explains that she also had to resist chaste Victorian prose just as she wished to avoid the new norm of plain English. What the translator must do is to "surrender" to the text, earning the right to "transgress from the trace of the other" (Spivak 1993: 178).

It is in describing this notion of "surrender" that Spivak opens her discussion onto the widest issues of subjective investment and loss in language. Translation has to do with loss of boundaries, loss of control, dissemination, the "spacy emptiness between two named historical languages" into which "meaning hops" (Spivak 1993: 180). The translator "juggles" the disruptive rhetoricity of the text, sensing "the selvedges of the languagetextile give way, fray into frayages or facilitations" (Spivak 1993: 180). Real translation can only come about if the "jagged relationship between rhetoric and logic, condition and effect of knowing" are reconstructed in the other language. This is the condition for an ethics of translation, "so that the agent can act in an ethical way [...] so that the agent can be alive, in a human way, in the world" (Spivak 1993: 181). There must in other words be an engagement between the translator and the textuality of the work, with the conditions of meaning and not just the ideas of the work. The translator, the agent of language, faces the text as a director directs a play, as an actor interprets a script. This cannot be the case when translation is taken to be a simple matter of synonymy, a reproduction of syntax and local colour (Spivak 1993: 179).

A translation might be produced if such a relationship is established, but it does not correspond to what Spivak sets out as an ethic of translation, which is to facilitate the love between the original and its shadow, "a love that permits fraying, holds the agency of the translator and the demands of her imagined or actual audience at bay" (Spivak 1993: 181). Spivak here echoes Walter Benjamin's idea that translation is not a communicative act (Benjamin 1969: 69). Like the "risky fraying" which accompanies "communication and reading of and in love", the act of translation brings with it the risk of a loss of agency.

This comparison to the experience of love allows Spivak to explore the relationship between self and other which is enacted through translation. Spivak posits two fundamental forms of alterity: the erotic and the ethical. In order to be ethical, she explains, we have to turn the other into something like the self. This is humanistic universalism: our moral obligations are built on the fundamental likeness between all human beings. But in the translating relationship there has to be more respect for the irreducibility of otherness this respect is more of an erotic than an ethical nature. The liberal, humanist "She is just like me" position is not very helpful when translating: it is maximum distance which the translator must seek. This brings the translating relationship ideally closer to the mode of the erotic rather than to the ethical form of alterity. ${ }^{2}$ 
This description of the erotic in translation could perhaps be read as a parodic inversion of George Steiner's description of the hermeneutic motion. Using aggressively male imagery, Steiner (1975: 298) describes the act of penetration of the text through which "the translator invades, extracts, and brings home." Steiner's four stages of entry into the text might begin in a passive moment of trust, but they end with a gesture of control. Spivak's movement of surrender is in stark contrast to Steiner's description, not only because it avoids masculinist images, but also because she insists on the ambivalent and uncertain "agency" of the translator. For Spivak, to engage with the text means a certain loss of rhetorical control, a subjugation to the imperatives of the rhetoricity of the original. Hers is less a hermeneutical voyage into the intentionality of the text than an engagement with the sensual texture of expression.

Spivak describes her translating method as follows. First, the translator must surrender to the text. She must "solicit the text to show the limits of its language, because that rhetorical aspect will point at the silence of the absolute fraying of language that the text wards off, in its special manner" (Spivak 1992: 181). The translator must earn the right to intimacy with the text, through the act of reading. Only then can she surrender to the text.

Spivak herself practices total surrender by providing a first translation at top speed. Surrender at that point mainly means being literal. The revision is not in terms of a possible audience but "in a sort of English," working against the text as "just a purveyor of social realism" (Spivak 1992: 188). Spivak sees no reason why translation has to be a slow and time-consuming affair. If the translator is prepared, possesses the necessary reading skills, the sheer material production could be very quick.

\section{TRANSLATION IN POSTCOLONIAL FRAME}

The most original aspect of Spivak's discussion of translation is its combined postcolonial and feminist frame. On the one hand, Spivak is sensitive to the political weight of language, and in particular the hegemonic position of English; on the other she recognizes the need for translation that is grounded in feminist solidarity. These tensions are not always recognized as conflictual, and Spivak is scathing in her critique of the insouciance with which cultural inequalities can be treated by First World feminists.

Translation is a practical necessity, she grants. It is important that the texts of women who write in Arabic or Vietnamese "be made to speak English" (Spivak 1993: 182). But is translation a form of hospitality or rather an expression of the law of the strongest? Spivak's discussion here recalls a long tradition of debate whose beginning can be found in Goethe's concept of Weltliteratur, a world literature which would contain within its borders the many diversities of national literary expression. Goethe's idea of Weltititeratur was shared by Madame de Stael. Both believe that the generalized interaction of literatures permitted by translation must be a permanent feature of cultural production, both believe that this interaction will provide for stronger, national literatures. The paradox of this position is picked up by Antoine Berman in his seminal work of translation theory in the Romantic period. He wonders whether there lies behind the idea of Weltliteratur the threat of cultural hegemony. For Berman, Goethe's idea of World literature seems to oscillate between two poles: one the one hand "World literature" would be a generalized movement of inter-translation, in which all cultures would translate one another; on the other, it would be a specifically German-language literary marketplace, defining German literature as the privileged access to literary universality (Berman 1984: 92). Does translation not become the expression of a strongly assimilationalist literary universe, carried by a single language? As Homi Bhabha asks, is Goethe's ideal of a world literature to be understood as the prefiguration of a harmonious universe of exchange or rather as a "form 
of cultural dissensus and alterity, where non-consensual terms of affiliation may be established on the grounds of historical trauma" (Bhabha 1994: 12)?

These questions very much echo Spivak's concern with the consequences of a generalized movement of translation of Third World literature into English. What are the practical and ideological effects of the large-scale transfer of these works towards English? Spivak's response to this question is contained in her exposition of translation method. Translation can attain the democratic ideal only if the rhetoricity, the textuality, of the work of Third World women is adequately rendered. A disrespectful rendering betrays the democratic ideal of translation.

Spivak very correctly indicates here that it is not the fact of translation itself which dictates its cultural meaning, but the manner of translation. It is not sufficient to count the number of translations in order to assess the dynamics of cultural exchange. What matters is the attention given to the textual specificity of the works.

Here is where Spivak provides her most cutting critique of Western feminist ideas about Third World solidarity. Access to other cultures, contrary to what many might think or hope, is not easy. It is not a question of devoting oneself to local or global social work. If you really want to establish solidarity, she asks, why not learn the mother-tongue of the women you are interested in? "In other words, if you are interested in talking about the other, and/or in making a claim to be the other, it is crucial to learn other languages" (Spivak 1993: 192). By "other" languages she is referring to those tongues generally learned only by anthropologists. This suggestion reaches to the heart of postcolonial inequities and to the ways they are reproduced in academic feminism and in cultural studies.

This critique is extended to Spivak's insistence on high standards of translation from Third World languages. Such standards, she understands, imply the risk of marginalizing the translator and the language of the original. Rigorous attention to the forms of expression of the foreign text run the risk of producing texts too opaque for immediate consumption, or too distant from prevailing esthetic norms. Yet these high standards must remain the translator's goal, and can be reached only if translators are well-prepared to take on their task. It is not sufficient to have depth of commitment to correct cultural politics. The translator must be familiar with the "history of the language, the history of the author's moment, the history of the language-in-and-as-translation" (1993: 186). To decide whether you are prepared enough to start translating, it might help if you have "graduated into speaking, by choice or preference, of intimate matters in the language of the original" (1993: 187).

The translator must know the difference between resistant and conformist writing by women, must know the literary scene, must be able to recognize that what seems resistant in the space of English may be reactionary in the space of the original. It may seem surprising that Spivak feels obliged to labour the point that the translator must be able to "discriminate on the terrain of the original" (1993: 189). One wonders what ignorance she is addressing when she insists that writers of a single "origin" should not be considered a homogeneous mass. She warns against the old colonial attitude of lumping together as one all work of exotic origin. The persistent heritage of this colonialism means that the accountability of translation is different when you are dealing with a language most reviewers do not know. This is part of the political import of translating from a Third World to a First world language.

The examples Spivak discusses are from her own and others' renderings of Bengali texts. She critiques a previous translation of the songs of Ram Proshad Sen "marred by the pervasive orientalism ready at hand" (Spivak 1993: 185) as a discursive system. Similarly a first translation of a story by Mahasweta Devi neglects the Bengali proverbs Devi cites (though they are startling, even in Bengali) and provides a naturalizing title: "The 
Wet-Nurse" where Spivak chooses "The Breast Giver," for its Marxian and Freudian associations.

Spivak's most fully developed display of translation is to be seen, of course, in the volume Imaginary Maps, which inserts three translated stories by Mahasweta Devi within the "embrace" of a multi-tiered commentary (Devi 1995). The book begins with a discussion between Spivak and the author, followed by the translator's preface, the texts themselves and then the translator's afterword. Spivak's careful enfolding of the text reflects her concern for the contextualization of all the voices which find expression in the book: the voice of the tribals of India, of Devi, of Spivak herself.

Spivak wishes so to counter the tendency towards the "uninstructed cultural relativism" of Third World literature courses and take seriously the role jokingly attributed to her of "dwarpalika" (female doorkeeper) of Mahasweta in the West (Devi 1995 : xxvi). Specificity and singularity is all-important, especially as Spivak addresses her double audience of US and Indian readers.

What kind of idiom does Spivak use in her translation? The English of Spivak's translations belongs, as she acknowledges, more to the "rootless American-based academic prose" than to the subcontinental idiom (Devi 1995: xxviii). When familiar terms of the vernacular are suggested, she gives "chick," "bad news," "what a dish," "blow him away." But the particularities of the translating idiom are more than that of (sexist) slang. The language of the translation is stark, angular; there is no softening of the harsh sequencing of phrases, no addition of mollifying connectives or literary-like phrases. Like Spivak's own prose, the stories are disconcerting in their erratic rhythms. Also like Spivak's own writing, they make swift leaps between disparate vocabulary registers. The English terms which appear in the original Bengali are italicized in the English version, to draw attention to the legacy of colonial English in the Bengali vernacular.

Spivak's translations enact a complex articulation of distance. This in turn reflects Spivak's readings of Devi's stories within the double context of postcolonialism and gender, of nationalism and sexuality, of the global and the local. In "Woman in Difference," her extended commentary on Devi's story "Douloti," Spivak refuses the "evolutionary lament stating that their problems are not yet accessible to our solutions and that they must simply come through into nationalism in order then to debate sexual preference" (Spivak 1993: 90). Her triple reading of Devi (using the triad of Marxism, deconstruction and feminism) militates at every point against an exoticizing of the social reality of the tribals, at the same time as it makes careful note of concrete specifics.

In her essay on "Douloti," Spivak explains Devi's rhetoric and the brutally dramatic effect of her prose. She explains in particular the concluding lines of the story which describe the decision of the dying Douloti to lie down in the clay courtyard of a school upon which a map of India has been traced. Here,

Mahasweta's prose, in a signature gesture, rises to the sweeping elegance of high Sanskritic Bengali. This is in the sharpest possible contrast to the dynamic hybrid medium of the rest of the narrative, country Hindi mixed in with paratactic reportorial prose. Echoes of the Indian national anthem can also be heard in this high prose. (Spivak $1993: 94$ )

Spivak translates:

Filling the entire Indian peninsula from the oceans to the Himalayas, here lies bonded labor spreadeagled, kamiya- whore Douloti Nagesia's tormented corpse, putrified with venereal disease, having vomited up all the blood in her dessicated lungs. [...] Today, on the fifteenth of August [Indian Independence day], Douloti (not as intending subject but as figured body) has left no room at all in the India of people like Mohan [the schoolmaster] for planting the standard of the Independence Flag. [...] What will Mohan do now? Douloti is all over India. (Spivak 1993: 94) 
Spivak's stark and defamiliarizing translations of Devi's stories carry an extraordinarily powerful charge, bringing the work of the Bengali writer, Mahasweta Devi, through the authority of Spivak's name and her erotics of translation, into the ongoing conversations of and on transnational culture. Here, contrary to usual practice, the name of the translator carries significant weight - creating a privileged channel through which this foreign work makes its way towards ready readers. Is there a paradox to be discovered in the contrast between Spivak's posture of "surrender" to the foreign text and her extensive critical interventions which mediate between the text and the English-language reader? For Spivak, both these postures belong to the esthetic and intellectual responsibilities of translation.

\section{POSTCOLONIAL PEDAGOGY}

Spivak's politics of translation must be seen as part of her larger project of postcolonial pedagogy. This involves, among others, the following principles: a continual insistence on the internal differences of the postcolonial nation ("India" explained as unending diversity), and an appreciation of the singular nature of the cultural forms produced by the Third World. This sensitivity to the historical and ongoing effects of imperial power is essential to the training needed for transnational cultural studies, argues Spivak, but it cannot come from English departments only. Anti-imperialist critique, she argues, cannot be fully contained by English - either the discipline, or the language. University curricula which train students for transnational cultural studies must recognize these limitations and should institute "a rigorous language requirement in at least one colonized vernacular" (Spivak 1993: 277).

Such a proposal would seem banal were it not such a rare occurrence within cultural studies. Indeed, Spivak seems to be one of very few theorists who draws attention to language as a necessary condition for understanding singular cultural forms. She warns that, if such sensitivity is not encouraged, new forms of Orientalism could emerge, which would include a canon of Third World Literature in translation, in which, in the words of Perry Anderson, "all alien shapes take on the same hue" (quoted by Spivak 1993: 278). We understand then how translation itself comes to nourish a program of anti-imperialist critique, by promoting the specificity of cultural forms. Spivak's own translations of a writer like Mahasweta Devi are clearly part of that project.

Although Spivak makes no reference to the poetry of Rabindranath Tagore, her discussion of the writing of Mahasweta Devi begs to be read in the context of this massive historical precedent. Tagore wrote in Bengali, as does Mahasweta Devi. And like Tagore, her international readership will be acquired through translation. However, while Tagore had a powerful intermediary to British culture in the person of Edward Thompson, as Devi does in Spivak, he took full responsibility himself for the English versions of his work.

The paradox of this choice, however, as has been astutely demonstrated by Sujit Mukherjee (1994: 113), is that "his own efforts [to translate himself] continue to be the greatest impediment to enjoyment and appreciation of modern India's greatest poet for those who have no choice but to read him in English." Tagore was not at all unaware of the transforming processes he imposed on his own poetry as he brought it into English. On the contrary, he seemed to have a very conscious and explicit idea of what the English public expected of him, and he intended to satisfy that expectation (Mukherjee 1994: 106). He subsequently simplified and edulcorated his poetry, earning a reputation for mysticism which he did not care to erase. Indeed he confessed to Edward Thompson that he had engaged in a career of "falsifying my own coins" (Mukherjee 1994: 122).

The goals and rules of cultural exchange for Tagore were dominated by the demands of colonialism. Tagore assumed that the cultural differences of his Bengali poetry would be tolerated only to the degree that it was assimilatable to the British literary canon. 
Indeed, although specialists like Edward Thompson objected to the simplification of Tagore's poetry, his work was otherwise received most positively. After all, Tagore surely won the 1913 Nobel prize on the basis of his work which was available in English. As Mahasweta Sengupta makes clear, Tagore's reputation and immense popularity in the West were not due primarily to an intellectual appreciation of his work but to an emotional association between the East and mysticism. Tagore actualized Western fantasies of the East as a place were "saints and prophets brought deliverance to ordinary people" (Sengupta 1990: 62). By his translations, Tagore was adding another piece to the existing edifice of Orientalism, making himself a representative of that otherness so alluring to the Western tradition.

The example of Tagore's self-translations are particularly revealing in that they are the product of a poet who was able to mold his work according to two contradictory sets of norms. As a poet and translator, Tagore lived in two separate and seemingly irreconcilable worlds. Each of these worlds defines itself in opposition to the other; and yet each claims roots in the authenticity of cultural purity. Spivak speaks of the pervasive orientalism which is "on hand" as a mode of relating to the Third World; Tagore's translations contributed to building and maintaining this discursive system.

The postcolonial frame of Spivak's "politics of translation" aims at revising the terms of cultural exchange as Tagore knew it. It is no longer a question of reshaping Indian literature into Anglo-American frame, but of distorting the frame of reception itself. The translator Spivak also lives in two worlds, but she wishes to change the terms obtaining between them. Her goal is not to valorize one in favour of the other, nor to separate out the strands which belong properly to one side or another of the cultural equation. Rather, it is to situate the critical project of translation within the parameters of an always evolving relationship between cultural poles.

The definition of this relationship is further complicated by the increasingly mobile boundaries of culture itself. Where once cultures were principally defined in reference to clearly circumscribed "national" or "ethnic" realities, it is the very boundedness of culture which has now become problematic. There is an emphasis now on the performative aspects of culture, on the ways in which cultural identity is constantly enacted through practices of representation. "American" culture, that is to say, now competes with a variety of other kinds of more specific forms of cultural identity ("feminist," "Chicano," "Black"), each employing vocabularies and images to affirm itself.

It is in their critique of the framing of culture that Spivak's politics of translation should be read, as well, in relation to the notion of "cultural translation" as developed by Homi Bhabha. Bhabha's theories emerge from concerns very similar to Spivak's: both are engaged in reconfiguring the boundaries of culture from the point of view of the postcolonial and the migrant. Both are concerned by the practice of translation. In rethinking culture as a category of enunciation, rather than a category of representation and knowledge, Bhabha elaborates a powerful conceptual frame for translation. Instead of serving as a bridge between already-given cultural entities, translation becomes an activity of cultural creation. The bridge, in other words, brings into being the realities which it links. ("The boundary becomes the place from which something begins its presencing," Bhabha 1994: 5). ${ }^{3}$

By translation I first of all mean a process by which, in order to objectify cultural meaning, there always has to be a process of alienation and of secondariness in relation to itself. In that sense there is no "in itself" and "for itself" within cultures because they are always subject to intrinsic forms of translation. (Bhabha 1990: 210)

In the hybrid culture, in the third space defined by Bhabha, which takes into account the unstable identities of the migrant, translation is a foundational activity. It is 
not confined to its traditional ancillary role as a medium of communication between nations, but elevated to a primary creative activity.

Translation is also a way of imitating, but in a mischievous, displacing sense - imitating an original in such a way that the priority of the original is not reinforced but by the very fact that it can be simulated, copied, transferred, transformed, made into a simulacrum and so on: the "original" is never finished or complete in itself. The "originary" is always open to translation so that it can never be said to have a totalised prior moment of being or meaning - an essence. (Bhabha 1990:210)

This reconfiguration of translation and displacement is possible because Bhabha operates in a conceptual world from which the conventional stabilities of nation/culture/ language/subject have disappeared. These terms are no longer to be considered in a logic of "diversity" or "plurality" (culture as the object of empirical knowledge, as a closed totality, an envelope which englobes and explains behaviour and ideas) but in a logic of "difference," as a process of negotiation.

Bhabha challenges the idea of culture as an envelope which securely binds all the members of a national community within the same coherence of meaning. The great migrations of postcolonialism have produced a new socio-demographic situation: all Western nations now have increasingly mixed populations. The ease and rapidity of global communication has created an international mass culture, which competes and interacts with local forms. Even those exotic cultures, which we once counted on to furnish simple counter-models to our own confusion, are as endangered as the fragile environment which once supported them. And so the idea of culture as a set of unchanging and coherent values, behaviours or attitudes, has given way to the idea of culture as negotiation, symbolic competition or "performance" (Clifford 1988). Every culture speaks a language traversed by two kinds of codes, the complicit idioms of the vernacular and the vehicular codes of international communication.

It is surprising, nevertheless, that Bhabha seems to be much less attentive than Spivak to the authority of the language of translation, the language which comes to enact and embody transnational culture. Using the theories of Walter Benjamin and de Man to highlight the irreducible specificity of the foreign signifier, Bhabha nonetheless draws little attention to the linguistic embeddedness of distant cultural material.

This is because the space which Bhabha works in is the liminary terrain of the transnational, that hybrid space which stands between the certainties of national cultures but does not participate in them. Unlike Spivak who engages in the practice of translation between cultures, insisting on the difference between the postcolonial and the migrant, Bhabha chooses to elaborate his own language of translation within the interstitial spaces of hybridity. This space is bracketed off from the traffic in ideas and texts which goes on in the more polarized spaces around it. Translation is not a mechanism of transfer or a naturalization of meaning, because the extremes of Otherness have collapsed into the ever-growing centre between them.

We can wonder, though, if this liminal, hybrid space of Bhabha does not too quickly occlude the signs of the linguistic differences which inhabit it. While Bhabha's own writing style promotes acute consciousness of the hybridity of its intellectual components, it is less sensitive to the linguistic expression of these differences. His writing is emblematic of the new internationalization of Anglo-American cultural studies, in that it seems to convey implicit assent to the dominance of the English language, and the implicit recognition of a single language of cultural expression. Here is enacted a curious law of the circulation of cultural goods. While the bulk of translation traffic today goes from English into other languages, the borders of cultural productions in English expand, becoming increasingly diasporic, occupying larger and larger chunks of territory. 
The increasing voracity of English to assimilate all cultures, to become the single vehicule of cosmopolitanism, is recognized by some American academics as a threat to cultural difference. Elaine Marks feels that the American university is at risk of being "devoured by the disease of monolingualism," facing the potential disappearance of languages and literatures other than English (Marks 1994: 368). And it could be shown that the English-dominated hybridity of cultural studies feeds the "devotedly monoglottal" tradition of American language-engineering policies (Shell 1993).

This is why Spivak's foregrounding of translation within her postcolonialist pedagogy is especially significant. She draws attention to the power of the implicit language of translation - its power of linguistic and esthetic assimilation. But Spivak's critique can be made to apply not only to postcolonial cultural studies but to the field of AngloAmerican translation as a whole. Her appeal to what Lawrence Venuti would call more "resistant" and less "fluent" translation practices feeds into a nascent critique of existing practices of translation within Anglo-American culture in general. This is a critique which Venuti has launched from within translation studies itself, arguing that a recognition of the "excluded theories and practices" of translation can serve a more democratic agenda (Venuti 1995: 40). In exposing the ethnocentric violence of much contemporary literary translation, in denouncing the "shadowy existence" of the translator within AngloAmerican culture, Venuti (1995:8) shows how esthetic and cultural Otherness has been controlled by translation. Venuti calls for alternative translating practices which will break this hold, which will offer "modes of cultural resistance" (1995: 309).

Like Berman and Venuti, Spivak proposes an ethics of translation based on the responsibility of the translator to be self-conscious and self-critical. Whether this ethic includes practices of "foreignizing" (Venuti) or attention to the "letter" (Berman) it is argued that the political agenda of translation is best pursued by foregrounding the act of mediation, by giving voice and body to the figure of the translator. What Spivak adds to this injunction is the reminder that this body is gendered, and that it operates from within a specific set of cultural relationships whose vectors of power can be influenced but not magically reversed by the act of translation.

\section{INCOMPLETE TRANSLATION}

Spivak's translation practice takes us far from the humanist ideal of translation serving in the creation of a "common Western culture," sustained by a universal human subject. The essential role played by translation in the creation of the great intellectual movements of Western civilization has always been recognized. Translation was central to the emergence of Christianity, to the renewal of learning during the late Middle Ages and the Renaissance, to the Europeanization of Romanticism - these examples are familiar. They are part of a discourse which defines translation as the principal instrument in the creation of our "common Western culture." George Steiner (1975: 247) says of translation during the time of the Renaissance that:

At a time of explosive innovation, and amid a real threat of surfeit and disorder, translation absorbed, shaped, oriented the necessary raw material $[. .$.$] it established a logic of relation$ between past and present, and between different tongues and traditions which were splitting apart under stress of nationalism and religious conflict.

We might wonder if the formative powers of translation today are working in the direction of the coherence imagined by Steiner, or rather towards increasing diffraction. Is it not perhaps that the solidity of these links is irrevocably lost, that the very "commonality" of culture is at risk? Cultural theorist Iain Chambers suggests that there is an incompleteness and a fragmentation inscribed into the logic of cultural communication: 
... There is a growing hesitancy in pretending to offer a rationalist synthesis of the voices and forces released in the post-colonial world, as if these can simply be plotred on to the existing map of knowledge. Sometimes the voices met with may converge, but they may also separate out to the point of incomprehension and dissonance [...] This suggests the need to connect without reducing to the same - those currents that seep through the contemporary critical world in the Occident, which, in condensed, displaced and partial fashion, seek to speak of an elsewhere, of other worlds, and whose co-presence and mixing disturb and decentre our previous sense of knowledge and being. It involves embracing a mode of thought that is destined to be incomplete. Western thought, with its promise of a mastery of the complete picture is confronted by the incompleteness of "the spilled, the broken world" to use Thomas Pynchon's memorable phrase: world broken down into complexities, diverse bodies, memories, languages, histories, differences. (Chambers 1994: 70)

Translation might once have been considered the instrument through which a "complete picture," an unbroken chain of tradition and a common contemporary culture, might have been achieved; today it inevitably partakes of the incompleteness of cultural belongings. The way we imagine translation is changed by the fact that the worlds which it seeks to bridge are already to some extent informed by plurality, are already saturated with a logic of translation.

The "incompleteness" of translation has been pointed to by the writers and theoreticians we have discussed. Homi Bhabha and Gayatri Spivak define translation as a difficult and never-ending transaction between the uncertain poles of cultural difference. It is not surprising that these concerns, currently applied to the context of culture and nation, find their origin in a common Derridean suspicion of foundational concepts. Rather than reconfirming the borders which separate nations, cultures, languages or subjectivities, translation shows them to be blurred. It is the very economy of translation as a system regulating differences which has become problematic.

How can translation act as an arbiter of culture, confidently recomposing the boundaries of the text, when the text itself challenges these limits? That translation can be the source of a unified tradition, a coherent linear framework for the transmission of meaning, is today no longer really available as an ideal. In a world of increasing diversity and competing interests, common norms are conjunctural and fluctuating. Models of universality are more often the reflection of figures of domination. We can wonder, however, if the idea of a unified common culture ever in fact became historical reality. Those spaces which were identified as universal (the great humanist tradition, the canon of great books, the public space associated with democratic communication, the model of culture which sustained the ideal of citizenship) have been exposed as being exclusionary. The universality attributed to these vectors of culture turns out to have been supported by the silencing of differences.

Divorcing itself from the unrealizable ideals of universal humanism, translation must work today through new logics of communication, through new configurations of commonality.

\section{Notes}

1. This is a shortened version of a text which has been published as the final chapter of Gender in Translation. Cultural Identity and the Politics of Transmission, Routledge, 1996.

2. In her essay on Irigaray, Spivak investigates the meaning of the contrast between the ethical and the erotic: "An ethical position must entail universalization of the singular. One can wish not to be excluded from the universal but if there is one universal, it cannot be inclusive of difference... For Irigaray, sexual difference is the limit to ethics" (Spivak 1993: 165).

3. Barbara Johnson also uses Heidegger's image of the bridge to describe translation. She quotes Heidegger as does Bhabha: "It does not just connect banks that are already there. The banks emerge as banks only as the bridge crosses the stream." Just as it is for Bhabha, this bridge is not a passive link coming "after" the 
banks of the river, but bringing these banks into existence. Johnson explains that "translation is a bridge that creates out of itself the two fields of battle it separates [...] The bridge of translation, which paradoxically releases within each text the subversive forces of its own foreignness, thus reinscribes those forces in the tensile strength of a new neighbourhood of otherness" (Johnson $1985: 148$ ).

\section{REFERENCES}

ARTEAGA, A. (Ed.) (1994): An Other Tongue: Nation and Ethricity in the Linguistic Borderlands, Durham and London, Duke University Press.

ASHCROFT, B., GRIFFITHS, G. and H. TIFFIN (1990): The Empire Writes Back, London and New York, Routledge.

BENJAMIN, W. (1969): “The Task of the Translator", Illuminations, trans. H. Zohn, New York, Schocken Books.

BERMAN, A. (1984): L'épreuve de l'étranger : culture et traduction dans l'Allemagne romantique, Paris, Gallimard.

BERMAN, A. (1985): Tours de Babel : essais sur la traduction, Mauvezin, Trans-Europ Press.

BERMAN, A. (1988): "De la translation à la traduction", $T T R, I, 1$, pp. 23-40.

BERMAN, A. (1992): The Experience of the Foreign, trans. S. Heyvaert, New York, State University of New York Press.

BERMAN, A. (1995): Pour une critique des traductions : John Donne, Paris, Gallimard.

BHABHA, H. K. (1990): "The Third Space", J. Rutherford (Ed.), Identity. Community. Culture. Difference, London, Lawrence \& Wishart.

BHABHA, H. K. (1994): The Location of Culture, London and New York, Routledge.

BRISSET, A. (1990): Sociocritique de la traduction: Théâtre et altérité au Québec (1968-1988), Longueuil, Le Préambule.

BROOKE-ROSE, C. (1968): Between, London, Michael Joseph.

BROSSARD, N. (1982): Picture Theory, Montreal, Éditions Nouvelle-Optique.

BROSSARD, N. (1983): These Our Mothers Or: The Disintegrating Chapter, trans, Barbara Godard, Toronto, Coach House Quebec Translations.

BROSSARD, N. (1985): La lettre aérienne, Montreal, L'Hexagone.

BROSSARD, N. (1987): Le désert mauve, Montreal, L'Hexagone.

BROSSARD. N. (1988) (1977): L'amer ou Le chapitre éffrité, Montreal, L'Hexagone.

BROSSARD, N. (1990): Mauve Desert, trans. S. de Lotbinière-Harwood, Toronto, Coach House.

BROSSARD, N. (1991): Picture Theory, trans. Barbara Godard, Montreal, Guemica.

BROWER, R. (Ed.) (1959): On Translation, New York, Oxford University Press.

BUTLER, J. (1990): Gender Trouble: Feminism and the Subversion of Identity, New York and London, Routledge.

CASTELLI, E. (1990): "Les Belles Infidèles / Fidelity or Feminism?", Special Section on Feminist Translation of the New Testament, Journal of Feminist Studies in Religion, pp. 25-39.

CAVE, T. (1979): The Cornucopian Text: Problems of Writing in the French Renaissance, Oxford, Clarendon Press.

CHAMBERLAIN, L. (1992): "Gender and the Metaphorics of Translation", L. Venuti (Ed.), Rethinking Translation: Discourse, Subjectivity, Ideology, London and New York, Routledge.

CHAMBERS, I. (1994): Migrancy. Culture Identity, London and New York, Routledge.

CISNEROS, Sandra (1991): Woman Hollering Creek and Other Stories, New York, Random House (Vintage).

CLIFFORD, J. (1988): The Predicament of Culture, Cambridge (Mass.) and London (England), Harvard University Press.

DERRIDA, J. (1974): “White Mythology”, trans. P.E. Lewis, New Literary History, 6, 1, pp. 5-74.

DERRIDA, J. (1979): "Living On / Border Lines", trans. J. Hulbert, H. Bloom (Ed.), Deconstruction and Criticism, New York, Seabury Press.

DERRIDA, J. (1985): "Tours de Babel", J. Graham (Ed.), Difference in Translation, Ithaca, Cornell University Press.

DEVI, M. (1995): Imaginary Maps, trans. G. Spivak, New York and London, Routledge.

FUSCO, Coco (1995): English is Broken Here: Notes on Cultural Fusion in the Americas, New York, The New Press.

GOUANVIC, J.-M. (1994): "La traduction et le devenir social: le cas de l'irruption de la science fiction américaine en France après la Seconde Guerre mondiale", TTR, "Genres littéraires et traduction", VII, 1 , pp. 117-152.

GRAHAM, J. F. (Ed.) (1985): Difference in Translation, Ithaca and London, Cornell University Press.

HERMANS, T. (Ed.) (1985): The Manipulation of Literature, Croom Helm.

HOFFMAN, E. (1989): Lost in Translation: A Life in a New Language, New York, Penguin.

JAKOBSON, R. (1959): "On Linguistic Aspects of Translation", R. Brower (Ed.), On Translation, New York, Oxford University Press. 
JANACZEWSKA, N. (1994): The History of Water / Huyen Thoai Mot Gionq Nuoc, Theatre Forum, 5, pp. 13-30. JOHNSON, B. (1985) : "Taking Fidelity Philosophically", Joseph F. Graham (Ed.), Difference in Translation, Ithaca and London, Cornell University Press.

LEFEVERE, A. (1992a) : Translation, Rewriting and the Manipulation of Literary Fame, London and New York, Routledge.

LEFEVERE, A. (Ed.) (1992b) : Translation / History / Culture: A Sourcebook, London and New York, Routledqe.

LEVINE, S. J. (1991) : The Subversive Scribe. Translating Latin American Fiction, Saint Paul (Minn.), Graywolf Press.

LEWIS, P. E. (1985) : "The Measure of Translation Effects", Joseph F. Graham (Ed.), Difference in Translation, Ithaca and London, Cornell University Press.

MACCORMACK, S. (1985) : “The Heart has its Reasons': Predicaments of Missionary Christianity in Early Colonial Peru", Hispanic American Historical Review, 65, 3, pp. 443-466.

MARKS (1994) :

MUKHERJEE, S. (1994): Translation as Discovery, London, Sangam Books.

NEEDHAM, R. (1972): Belief Language and Experience, Chicago, Chicago University Press.

NIDA, E. (1959): "Principles of Translation as Exemplified by Bible Translating", R. Brower (Ed.), On Translation, New York, Oxford University Press.

NIDA, E. and J. de WAARD (1986): From One Language to Another: Functional Equivalence in Bible Translating, Nashville, Camden and New York, Thomas Nelson Publishers.

NIRANJANA, T. (1992): Siting Translation: History. Poststructuralism, and the Colonial Context, Berkeley, Los Angeles, Oxford, University of California Press.

NORTON, G.P. (1984): The Ideology and Language of Translation in Renaissance France, Genève, Droz.

PRATT, M. L. (1987): “Linguistic Utopias", N. Fabb (Ed.), The Linguistics of Writing, Manchester, Manchester University Press.

PRATT, M. L. (1991): "Arts of the Contact Zone", Profession 91, New York, Modern Language Association.

PRATT, M. L. (1992): Imperial Eyes: Travel Writing and Transculturation, London and New York, Routledge.

RAFAEL, V. (1988): Contracting Colonialism: Translation and Christian Conversion in Tagalog Society under Early Spanish Rule, Ithaca and London, Cornell University Press.

RUSHDIE, S. (1991): Imaginary Homelands, London, Granta.

SENGUPTA, M. (1990): "Rabindranath Tagore in Two Worlds", S. Bassnett and A. Lefevere (Eds), Translation, History and Culture, London and New York, Pinter Publishers.

SHELL, M. (1993): "Babel in America; or, the Politics of Language Diversity in the United States", Critical Inquiry 20, 1, pp. 103-127.

SIMON, S. (1982): "How to Speak White in Four Thousand Languages: The Summer Institute of Linguistics in Ecuador", This Magazine, June, pp. 33-36 (reprinted in The Humanist, Spring 1983, pp. 33-36.)

SIMON, S. (1992): "The Language of Cultural Difference: Figures of Alterity in Canadian Translation", L. Venuti (Ed.), Rethinking Translation: Discourse, Subjectivity Ideology, London and New York, Routledge.

SIMON, S. (1994): Le Trafic des langues. Traduction et culture dans la littérature québécoise, Montreal, Éditions du Boréal.

SIMON, S. (Ed.) (1995): Culture in Transit. Translation and the Changing Identities of Québec Literature, Montreal, Vehicule Press.

SNELL-HORNBY, M. (1988): Translation Studies: An Integrated Approach, Amsterdam and Philadelphia, John Benjamins.

SPIVAK, G. (1981): "French Feminism in an International Frame", Yale, French Studies, 62, pp. 154-184.

SPIVAK, G. (1990) (Ed.): S. Harasym, The Postcolonial Critic: Interviews. Strategies, Dialogue, New York and London, Routledge.

SPIVAK, G. (1992): “Acting Bits / Identity Talk", Critical Inquiry, 18, pp. 770-803.

SPIVAK, G. (1993): "The Politics of Translation", Outside in the Teaching Machine, New York and London, Routledge.

STAEL, Germaine de (1821): Cuvres complètes, Paris, Treuttel et Wurtz, tome XVII.

STAEL, Germaine de (1935): De la littérature considerée dans ses rapports avec les institutions sociales, Paris, Larousse.

STAEL, Germaine de (1967): De l'Allemagne, Paris, Garnier-Flammarion.

STEINER, G. (1975): After Babel, London and Toronto, Oxford University Press.

TOURY, G. (1995): Descriptive Translation Studies and Beyond, Philadelphia, John Benjamins.

VENUTI, L. (1992) (Ed.): Rethinking Translation: Discourse. Subjectivity Ideology, London and New York, Routledge.

VENUTI, L. (1995): The Translator's Invisibility, London and New York, Routledge. 